
and Aromatic Plants

An International Journal

ISSN: 2619-9645 | e-ISSN: 2667-5722

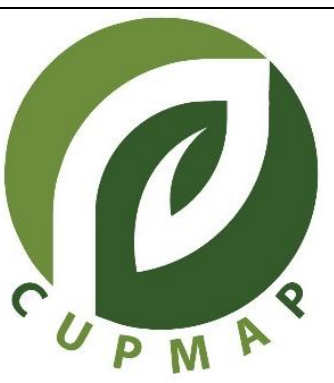

\title{
Antimicrobial Activity of Leaf, Fruit, and Gall Extract of Pistacia terebinthus Growing in Tessala

\author{
Bellifa NAZIM ${ }^{*}$ iD, Ferkous HOUSSEM ${ }^{2}$, Benhaddou ISMAIL ${ }^{3}$ iD, \\ Merad YASSINE 4 (iD), Matmour DEROUICHA ${ }^{5}$
}

\begin{abstract}
${ }^{* 1}$ Department of Pharmacy, Pharmacognosy Laboratory, Faculty of Medecin, University Djilali Liabes, Postal code 22000, City Sidi Bel Abbes, Country Algeria , E-mail: nazim.bellifa@univ-sba.dz , ORCID ID: 0000-00024247-1850

${ }^{2}$ Department of Pharmacy, Laboratory of Botany, Faculty of Medecin, University Djilali Liabes, Postal code 22000, City Sidi Bel Abbes, Country Algeria

${ }^{3}$ Department of Pharmacy, Pharmacognosy Laboratory, Faculty of Medecin, University Djilali Liabes, Postal code 22000, City Sidi Bel Abbes, Country Algeria

${ }^{4}$ Department of Pharmacy, Laboratory of Microbiology, Faculty of Medecin, University Djilali Liabes, Postal code 22000, City Sidi Bel Abbes, Country Algeria

${ }^{5}$ Department of Pharmacy, Therapeutic Chemistry Faculty of Medecin, University Djilali Liabes, Postal code 22000, City Sidi Bel Abbes, Country Algeria
\end{abstract}

\begin{abstract}
Nature is a large deposit of active molecules of plant origin, and the resources of the flora are far from being fully inventoried. Today, the world continues to search for plants that can be used as the basis for new and relatively new treatments. In vitro antibacterial activity was evaluated on the $\mathrm{MeOH}$ extract of leaves, fruit galls, and essential oil mastic gum of Pistacia terebinthus from Tessala (Western Algeria) against four human pathogenic microorganisms (Escherichia coli, Bacillus subtilis, Pseudomonas aeruginosa, and Staphylococcus aureus) using a disc diffusion method. The gall extract revealed a remarkable antimicrobial effect against the tested microorganisms. Strong activity was observed for samples of gall extract against Staphylococcus aureus with inhibition zones of $20 \mathrm{~mm}$. These results suggested that the samples of gall extract of $P$. terebinthus tested for antimicrobial activity can be listed as bactericides.
\end{abstract}

Key Words: Antimicrobial activity, Galls, Pistacia terebinthus, Tessala

(C) CUPMAP. All rights reserved.

\section{Introduction}

Nature is a huge deposit of active molecules of plant origin, and the resources of the flora are far from being fully inventoried. Today, the world continues to search for plants that can be used as the basis for new and relatively new treatments, this systematic search for the therapeutic resources of aromatic and medicinal plants opens up extremely promising prospects for the pharmaceutical industry (Guedira, 2008).

The terabinth is a shrub from 2 to 3 meters, deciduous, imparipinnate giving red drupes where it is generally found at rocky sites with open vegetation; it avoids the driest and coldest locations and distribution It is found in all parts of the West from Portugal to Turkey and Morocco to Libya, it penetrates 
quite deeply in the southern Alps. In Algeria, the genus Pistacia is represented by four species, namely Pistacia terebinthus Pistacia vera, Pistacia atlantica, and Pistacia lentiscus. (Quezel, 1962; Lapie and Maige, 1914).

Galls are remarkable plant structures that have been observed, studied, and used since antiquity. They are abnormal growths in plants, induced by viruses, bacteria, fungi, nematodes, and arthropods, in a wide variety of plant families. Pistacia common plant galls with therapeutic applications, some aphids species induce the formation of different galls in Pistacia terebinthus, Forda formicaria, F. marginata, Paracletus cimiciformis, Geoica utricularia, and Baizongia pistacia, most of them are irregular, globose, chili, coral, cauliflower, curved, but another one gets the shape of fruits, identification of them in their geographical range is based on gall characteristics as well as on aphid morphology (Blackman and Eastop, 1994; Piras et al., 2017).

The terebinth pistachio tree is particularly sensitive to this type of insects that transform leaflets to reddish the ecological niche with distinctive architecture, the artwork of aphids which hem the leaflets. This phenomenon attracts the attention of ecologists and biologists for a long time. Gallformers are parasitic organisms that manipulate plant traits for their benefit. Galls have been shown to protect their inhabitants from natural enemies such as predators and parasitoids by various chemical and mechanical means. Much less attention, however, has been given to the possibility of defense against microbial pathogens in the humid and nutrient-rich gall environment. (Álvarez et al., 2016).

A few research on the chemical composition and biological activities of $P$. terebinthus were made tree. Because the chemical composition of leaves fruit differs significantly from those of galls, the goal of this study is to determine the antimicrobial activity focused on the leaves, fruits, galls, and essential oil of mastic gum (Piras et al., 2017).

\section{Material and Methods}

\subsection{Vegetal material}

Leaves, fruits, and galls of $P$. terebinthus were collected from Tessala mountain (Western Algeria). Samples were taken in September and November at sites in the west of the province of Sidi Bel Abbes (Algeria). Samples were collected from the last stages of development of the galls (Fig 1).

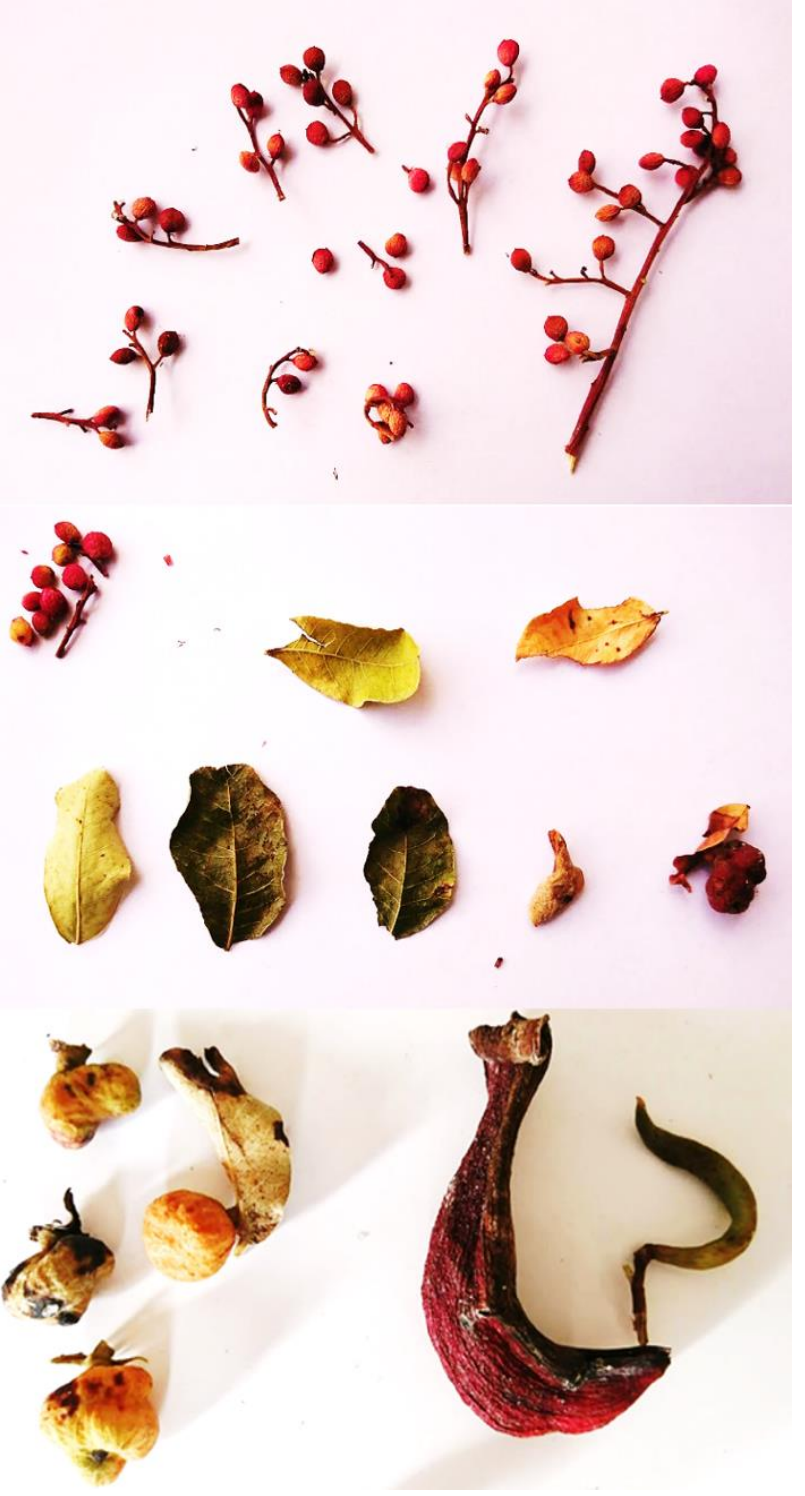

Fig 1. Morphological aspects of fruit and gall leaves of Pistacia terebinthus 


\subsection{Extraction}

The routine extraction method that we use is maceration by solvents of increasing polarity. The $\mathrm{MeOH}$ extract of the aerial part of Pistacia terebinthus is prepared from $20 \mathrm{~g}$ of grinding of the leaves, fruits, and galls, which are macerated in $500 \mathrm{ml}$ of methanol at room temperature and protected from light for 24 hours, with maximum stirring. The mixture is then filtered on a paper filter. The operation is repeated a second time on the mark. The filtrates obtained are added and evaporated to dryness with the aid of a rotary evaporator «BÜCHI» at a temperature of $40-50^{\circ} \mathrm{C}$, then the dry extract is kept in the refrigerator

\subsection{Antibacterial activity}

The evaluation of the antibacterial activity was carried out by the method described by (Pfaller and Herwaldt, 1997) and (Selka et al., 2016) by diffusion on disks in an agar medium, this method allows an estimation of the inhibition of the growth of the microorganisms which is estimated in terms of the diameter of the zone of inhibition of the microbial growth around the disks containing the samples to be tested after $24 \mathrm{~h}$ of incubation at an adequate temperature of $37^{\circ} \mathrm{C}$. The $\mathrm{MeOH}$ extract of the galls, the $\mathrm{MeOH}$ extract of the leaves, fruit, and essential oil mastic gum of $P$. terebinthus are dissolved in DMSO dimethylsulfoxide. We used 4 bacterial strains of the ATCC type from the Institut Pasteur in Algiers: Escherichia coli ATCC 25922, Staphyloccocus aureus ATCC 25923, Bacillus cereus ATCC 11778 Pseudomonas aereginosa ATCC 9027).

The culture medium consists of MullerHinton and $20 \mathrm{~g}$ of Agar-agar adjusted to a $\mathrm{pH}$ of 7.4, the agar is poured into Petri dishes 90 $\mathrm{mm}$ in diameter. The preparation of bacterial inoculum is usually carried out after several steps. Initially, the samples kept refrigerated must be activated in a liquid $\mathrm{MH}$ medium after 24 hours at $35^{\circ} \mathrm{C}, 1 \mathrm{ml}$ of standardized bacterial inoculum $(108 \mathrm{CFU} / \mathrm{ml})$ is aseptically deposited and spread on the surface of the medium with the aid of a stall, the excess liquid is sucked with a sterile pasture pipette. The disks $(\varnothing 0.5 \mathrm{~cm})$ are impregnated with a variable quantity (between 1 and $10 \mu \mathrm{l}$ ) of the selected product and placed on the inoculated agar. Negative controls are prepared using DMSO. Ampicillin is used as a positive reference to determine the sensitivity of each bacterium. The Petri dishes are then incubated for 24 hours at $37^{\circ} \mathrm{C}$. The antibacterial activity is evaluated by measuring the diameter of the inhibition zone. The categorization of bacterial strains concerning the extracts tested is as follows: susceptible strains $S$ $(\emptyset \geq 11 \mathrm{~mm})$; intermediate strains I $(5 \mathrm{~mm}<\varnothing<11 \mathrm{~mm})$ and resistant strains $\mathrm{R}(\varnothing \leq 5 \mathrm{~mm}) . \varnothing$ : diameter of the inhibition zone, according to the European committee on Antimicrobial Susceptibility.

\section{Results and Discussion}

The results of the antibacterial activity of the various extracts are presented in Table 1. In vitro antibacterial activity was evaluated on the $\mathrm{MeOH}$ extract of leaves, fruit galls, and essential oil mastic gum of $P$. terebinthus in the presence of positive control of ampicillin. The essential oil of galls has greater antibacterial activity than that of other extracts with an inhibition diameter ranging from 5 to $20 \mathrm{~mm}$.

The results show that the extracts have antimicrobial activities of varying degrees according to the strains of the different microorganisms tested, it is observed that the large inhibition zones appear with the extract of essential oil mastic gum HE (3) and the extract of the gall (4) on Staphylococcus aureus. For the $\mathrm{MeOH}$ extract of the leaves (2), there is minimal inhibition against the three strains: Staphylococcus aureus, Escherichia coli, and Bacillus subtilis (low activity), and Pseudomonas aeruginosa show a negative result (no inhibition). The extract of the fruit 
(1) exhibits moderate activity, the latter showing zones of inhibition with the four strains. This analysis shows that the most important inhibitory effect is obtained by the $\mathrm{MeOH}$ extract of galls with Staphylococcus aureus (Gram-positive), where a large inhibition zone is observed.

Table1. The results of the antibacterial activity of the various extracts

\begin{tabular}{l|l|l|l|l}
\hline Produits & $\begin{array}{l}\text { E. coli } \\
\text { D C }\end{array}$ & $\begin{array}{l}\text { B. subtilis } \\
\text { D C }\end{array}$ & $\begin{array}{l}\text { P. aereginosa } \\
\text { D C }\end{array}$ & $\begin{array}{l}\text { S. aureus } \\
\text { D C }\end{array}$ \\
\hline 1/ fruit extract & 9 I & 14 S & 12 S & 13 S \\
\hline 2/ leave extract & 7 I & 9 I & 5 R & 9 I \\
\hline 3/ mastic & 5 R & 12 S & 11 S & 13 S \\
\hline 4/ galls extract & 12 S & 11 S & 9 I & 20 S
\end{tabular}

D: diameter of the inhibition zone; C: categorization of strains, S: sensitive; I: intermediary; R: resistant.

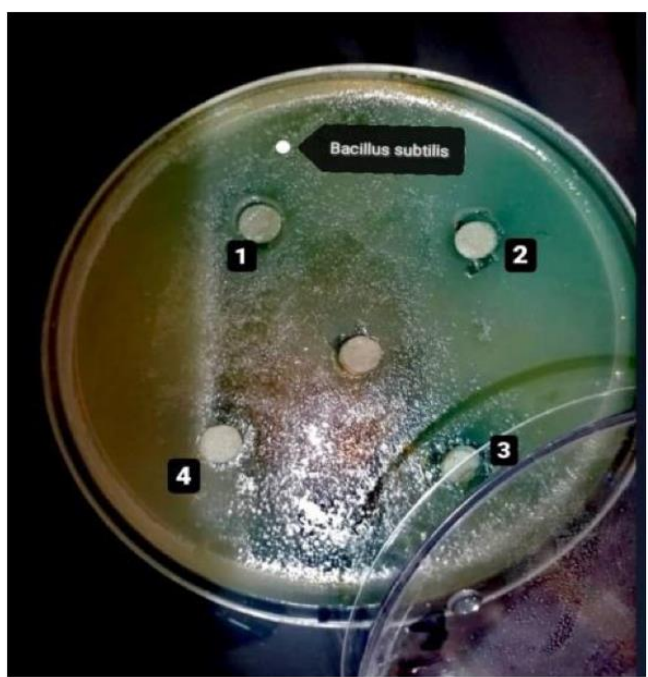

Bacillus subtilis

ATCC 11778

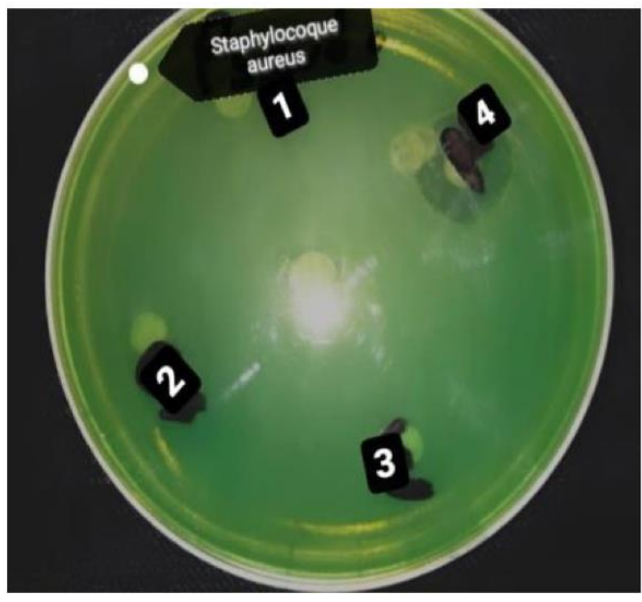

Staphylococcus aureus ATCC 25923

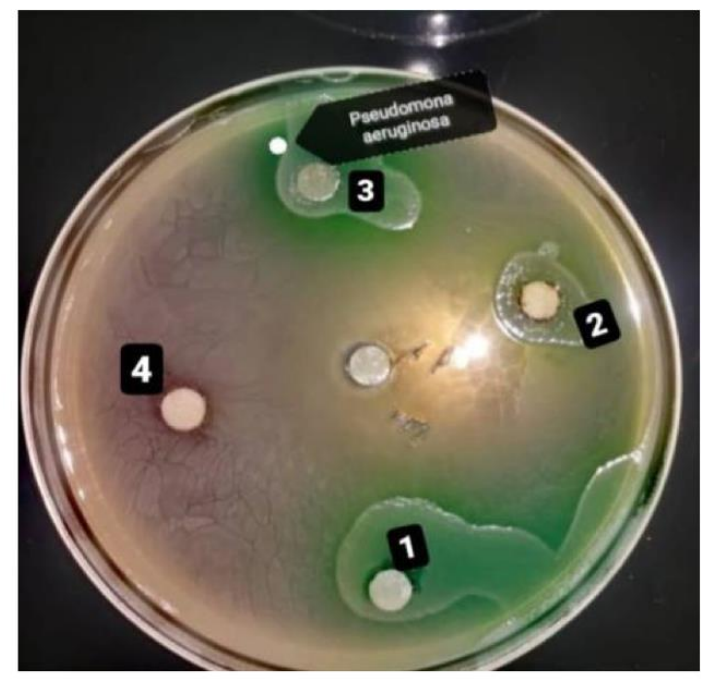

Pseudomonas aeruginosa ATCC 9027

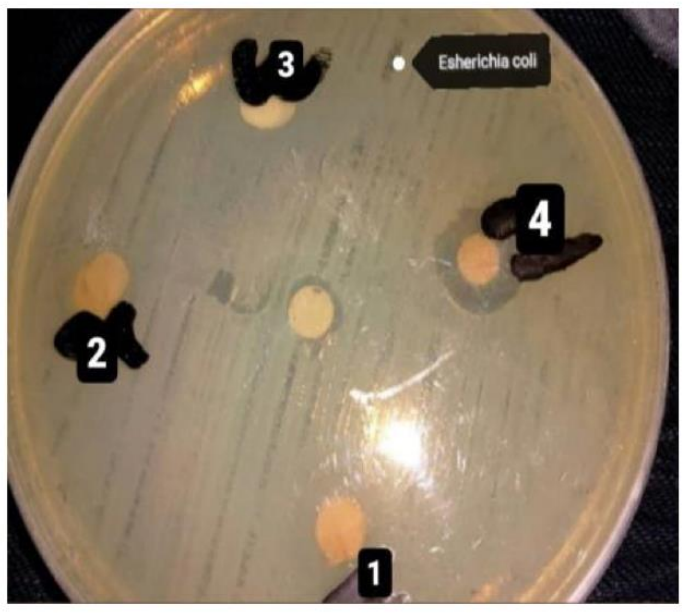

Esherichia coli

ATCC 25922

Fig 2. Antibacterial activity of different parts of Pistacia terebinthus $\mathrm{MeOH}$ fruit extract (1); $\mathrm{MeOH}$ extract of leaves (2); Essential oil of mastic gum extract (3), $\mathrm{MeOH}$ galls extract (4) 
The various extracts of $P$. terebinthus showed significant antibacterial activity against various Gram-positive and Gramnegative bacteria, as has already been specified. The antibacterial activity in vitro is estimated on the methanolic extract of the leaves, fruit, galls of $P$. terebinthus, essential oil mastic gum of $P$. terebinthus extract in the presence of positive control of ampicillin. The essential oil of galls has greater antibacterial activity than that of other extracts with an inhibition diameter ranging from 9 to $20 \mathrm{~mm}$. The antibacterial activity depends on the nature of the active secondary metabolites but especially on the nature of the Gram+ or Gram- bacteria and also on the extraction method carried out. Moreover, it has been known since antiquity that essential oils exhibit a non-negligible antiseptic activity (Pulaj et al., 2016; Piras et al., 2017).

The high activity of Pistacia's essential oils is mainly due to its richness with active compounds such as terpenes and essentially phenols. the essential oil of this plant has a very high antibacterial power on several bacterial strains. In addition, other works show the value of Pistacia essential oils. These results are consistent with the work of Ibrahim SIFI et al., who studied the antimicrobial activity of essential oils of Pistacia atlantica galls from three southern Algerian regions on six microbial strains, the study revealed a significant action against Gram-positive bacterial strains with a MIC of 0.44 for Bacillus cereus. Several studies show that Gram-positive bacteria are highly sensitive to Gram-negative bacteria, which can be attributed to the difference in the outer layers of Gram-negative bacteria compared to Gram-positive bacteria (Alma et al., 2004; SIFI, 2020).

The difference in antibacterial activity found between the methanolic extract of leaves, fruits of galls, and putty could be explained by the fact that the essential oil of Pistacia terebinthus contains $90 \%$ of the monoterpenes including alpha-pinene, Limonene reputed by their antiseptic power, while the methanolic extract is more concentrated in phenolic compounds to $80 \%$ of the tannins and flavonoids of high molecular weight catechin which influence their passage through the bacterial membrane. One study indicated that the antibacterial activity of $P$. terebinthus essential oil can be attributed to the combination of several compounds. Alpha pinene, terpineol, and linalol showed high antibacterial activity against Escherichia coli, Staphylococcus aureus and Bacillus subtilis, comparable to that of mastic oil (Kivcak et al., 2004; Ulukanli et al., 2014).

\section{Conclusion}

This work is a contribution to the valorization of aromatic and medicinal plants in Algeria in the region of Tessala. The gall extract revealed a remarkable antimicrobial effect against the tested microorganisms. Strong activity was observed for samples of gall extract against Staphylococcus aureus with inhibition zones of $20 \mathrm{~mm}$ (for $50 \mu \mathrm{l}$ ). These results suggested that the samples of gall extract of $P$. terebinthus tested for antimicrobial activity can be classified as bactericides.

\section{Acknowledgements}

The authors thank Prof. Dr. Chelghoum for his assistance and all the members of pharmacognosy Laboratory. Thanks, are also due to Prof. Dr. Yebous for his contribution and assistance and Prof. Dr. Achouri.

\section{Author Contribution}

B.N.: Drafting the research protocol, Identification of plants, Manuscript writing, F.H.: Identification of plants, M.D.: Discussion, Corrections. B.I.: extraction, control. M.Y.: Conducting the antibacterial activity. All authors reviewed, commented, and approved the final manuscript. 


\section{Conflicts of Interest}

The authors have no conflicts of interest to declare and disclose any financial field.

\section{References}

1. Alma, M. H., Nitz, S., Kollmannsberger, H., Digrak, M., Efe, F. T., \& Yilmaz, N. (2004). Chemical composition and antimicrobial activity of the essential oils from the gum of Turkish pistachio (Pistacia vera L.). Journal of Agricultural and Food Chemistry, 52(12), 3911-3914. https://doi.org/10.1021/jf040014e

2. Álvarez, R., Martinez, J.-J., Muñoz-Viveros, A. L., Molist, P., Abad-González, J., \& Nieto Nafr \’\ia, J. M. (2016). Contribution of gall microscopic structure to taxonomy of gallicolous aphids on Pistacia. Plant Biology, 18(5), 868-875.

3. Blackman, R. L., \& Eastop, V. F. (1994). Aphids on the world's trees. An identification and information guide. CAB International. NHM, University Press, Cambridge.

4. Guedira, K, G. P. (2008). les plantes médicinales (second Edi; Readers Digest, Ed.). Paris.

5. Kivcak, B., Akay, S., Demirci, B., \& Bacser, K. (2004). Chemical composition of essential oils from leaves and twigs of Pistacia lentiscus, Pistacia lentiscus var. chia, and Pistacia terebinthus from Turkey. Pharmaceutical Biology, 42(4-5), 360-366.

6. Lapie, G., \& Maige, A. (1914). Flore forestière illustrée, comprenant toutes les espèces ligneuses de l'Algérie et les espèces ligneuses les plus répandues en Tunisie, au Maroc et dans le midi de la France; pour la détermination facile, sans l'emploi de mots techniques, de touutes les. Paris: E. Orlhac.

7. Pfaller, M. A., \& Herwaldt, L. A. (1997). The clinical microbiology laboratory and infection control: emerging pathogens, antimicrobial resistance, and new technology. Clinical Infectious Diseases, 858-870.

8. Piras, A., Marzouki, H., Maxia, A., Marengo,
A., Porcedda, S., Falconieri, D., Salgueiro, L. (2017). Chemical characterisation and biological activity of leaf essential oils obtained from Pistacia terebinthus growing wild in Tunisia and Sardinia Island. Natural Product Research, 31(22), 2684-2689.

https://doi.org/10.1080/14786419.201 7.1289204

9. Pulaj, B., Mustafa, B., Nelson, K., Quave, C. L., \& Hajdari, A. (2016). Chemical composition and in vitro antibacterial activity of Pistacia terebinthus essential oils derived from wild populations in Kosovo. BMC Complementary and Alternative Medicine, 16(1), 147.

10. Quezel,P,S.S.(1962).Nouvelle_Flore_de_l'A lgérie_et_des_régions_désertiques_méridio nales_Tome1.pdf. P: Paris.

11. Selka, M. A., Chenafa, A., Achouri, M. Y., Aoued, L., Tareb, S., Nourredine, M. A., \& Toumi, H. (2016). Activité antimicrobienne et antioxydante des feuilles de Vitis vinifera L. Phytotherapie, 14(6), 363-369.

12. https://doi.org/10.1007/s10298-0161036-5

13. Sifi, I. (2020). Activites biologiques et antioxydantes des huiles essentielles des galles de pistacia atlantica. Université de Laghouat-Amar Telidji Algeria.

14. Ulukanli, Z., Karabörklü, S., Öztürk, B., Çenet, M., \& Balcilar, M. (2014). Chemical Composition, Antibacterial and Insecticidal Activities of the Essential Oil from the $\mathrm{P}$ istacia terebinthus $\mathrm{L}$. Spp. Palaestina (Boiss.) (Anacardiaceae). Journal of Food Processing and Preservation, 38(3), 815-822. 